\title{
CULTURA VISUAL E PEDAGOGIA DA IMAGEM: RECUOS E AVANÇOS NAS PRÁTICAS ESCOLARES
}

Heloísa Andreia de Matos Lins*

A visão é uma construção cultural, que se aprende e cultiva [...] e está profundamente envolvida com as sociedades humanas, com a ética e a política, com a estética e a epistemologia

de ver e de ser visto. (MITCHELL, 2002, p.166 apud DUSSEL, 2012, p.4)

\section{Algumas cenas da historiografia educativa em relação às tecnologias, mídias e imagens}

As reflexões trazidas à tona aqui destacam a cultura visual, compreendida para além de um repertório de imagens, ou seja, como um conjunto de discursos visuais que constroem posições e que estão inscritos em práticas sociais, intimamente relacionados às instituições que nos concedem o "direito ao olhar", em particular, a escola, que se propõe a disciplinarizar os olhares (na perspectiva foucaultiana no que tange aos corpos/mentes), organizando um campo do visível e do invisível, do belo e do feio, como nos lembra Dussel (2012, p.4). É nesse sentido que a pedagogia da imagem será também colocada em foco. Quais são, afinal, as possibilidades de transformação nas práticas pedagógicas, a partir do uso das imagens e das tecnologias? São realmente necessárias? Trouxeram/trazem

\footnotetext{
* Doutora em Educação pela Faculdade de Educação da Universidade Estadual de Campinas (Unicamp); Professora do Departamento de Psicologia Educacional da Faculdade de Educação (FE) da Universidade Estadual de Campinas (UNICAMP). E-mail: hmlins@unicamp.br.
} 
de fato novidades ao que já era realizado? Como a cultura visual influencia tais decisões em âmbito escolar e como a escola participa da construção dessa forma cultural, ao longo da história?

Embora saibamos que a "didatização das imagens" ou "dos olhares" não se trata de um fenômeno exclusivamente escolar, haja vista o papel que exercem os jornais para com as fotos de guerras ou que retratam grandes sofrimentos, como ratificou Susan Sontag (2003, p.14), quando disse que "todas as fotos esperam por sua vez de serem explicadas ou deturpadas por suas legendas", a escola legitima-se (entre outras instâncias) como lócus privilegiado para a veiculação de ideologias que usam ou "criam arquivos de imagens comprobatórias, imagens representativas, que englobam ideias comuns de relevância e desencadeiam pensamentos e sentimentos previsíveis" (SONTAG, 2003, p.73). Embora Sontag não trate especificamente da questão pedagógica/escolar, defendeu que toda imagem seria um convite livre ao olhar e evidenciou as questões ideológicas acima apontadas, disseminadas de forma mais ampla na(s) cultura(s) e, portanto, nas práticas sociais, o que implica, certamente, um movimento de influência dialética de tais práticas com o fazer pedagógico cotidiano.

Nessa via de mão dupla, como argumenta Dussel (2012), a escola contribuiu com a formação dos sujeitos visuais contemporâneos, participando ativamente da formação de nossa cultura visual. A autora salienta que as escolas e os docentes em particular têm sido centrais na transformação dos regimes escópicos da atualidade. Conseguir a atenção do espectador e também do aluno se tornou um elemento chave da ação educativa, tanto da escola como de outros meios, como as salas de pintura, as exposições universais e o cinema. Para Dussel (2012), apesar de todas as críticas em relação à escola e da ênfase no declínio dessa instituição como espaço público de aprendizagens significativas, esta se torna a mais importante em caracterizar algum "sentido comum", de certa forma livremente, em relação à cultura letrada: “[...] são as únicas instituições que 'se preocupam' com os efeitos que a cultura e a sociedade produzem nos sujeitos [...] a educação visual do espectador e do público é feita por muitas agências"1 (DUSSEL, 2012, p.9).

Para Martín-Crossa (apud DUSSEL, 2012), a escola básica estrutura um modelo de transmissão de conhecimentos que organiza o campo de conhecimentos e também o estético de um certo modo. Além disso, segundo o autor, a escola possui os seguintes traços: é niveladora (porque 
estabelece uma "rasante indiscriminação" numa "cadeia de formas iguais e intercambiáveis"), enfática (porque hierarquiza e privilegia certos feitos e oferece pautas de ação), mitificadora (porque busca proporcionar modelos que sejam imagens "fortemente dotadas de ideais e nós de significação em que se condensam normas, aspirações e inquietudes"), formal (porque quer "O asseio e o esmero") e operacional (porque entrega "elementos simples e intercambiáveis" para edificar cadeias e configurações mais complexas). De modo geral, ressalta-se a capacidade da escola de impregnar um imaginário nacional, proporcionando materiais e imagens para a criação estética e também modos de ativação, ações ou procedimentos (como armar, construir, justapor, mesclar, etc.) (DUSSEL, 2012, p.12).

Nessa direção, a pedagogia vem-se utilizando de muitas formas visuais, e todas foram maneiras de educar os modos de ver dos escolares e os sentidos que deviam construir-se em torno das experiências visuais e da busca pela "verdade". Por outra perspectiva, a escola assume a constante desconfiança em torno das imagens, apoiada na tradição platônica a esse respeito, isto é, se, por um lado, as imagens são necessárias à escola, para captar a sensibilidade, subsidiar a memória e permitir que se represente aquilo que não poderia ser pensado, por outro, são condenáveis porque distraem a inteligência do essencial. Será o movimento escolanovista que denunciará o caráter perigoso da imagem, na qual se vislumbra uma ferramenta de doutrinação das mentalidades (DUSSEL, 2012).

Para a referida autora, a escola assumiu uma atitude constante de suspeita para com a cultura visual, principalmente em relação à cultura visual de massas:

[...] a la que consideró desde trempano una fuente de degeneración moral e intelectual de la población ${ }^{2}$ - y esto es cierto aún para aquellos educadores enrolados en la educación popular, que sostuvo esa misma posición de desprecio moral a los massmedia ${ }^{3}$ (GOODWYN, 2004 apud DUSSEL, 2012, p.7).

Um exemplo emblemático dessa posição de desprezo em relação às "novas mídias/tecnologias" - que de novas só têm a roupagem ${ }^{4}$ - foi representada por Víctor Mercante, um pedagogo argentino "modernizador", que atuou no início do século XX e que (como muitos adeptos à época e atualmente) rechaçava severamente o cinema e a posição dos jovens que obviamente manifestavam, de forma clara, o chamado prazer 
escópico, o prazer de olhar, de sentir, de se impressionar. Para Mercante, os jovens só queriam "gozar, gozar, gozar" (MERCANTE, 1925 apud DUSSEL, 2012, p.5), e, por conseguinte, o cinema seria uma escola de perversão criminal. Desse ponto de vista, as escolas deveriam organizar comitês de censura em todas as cidades, para que somente filmes "moralmente edificantes" fossem exibidos.

Tendo identificado "os monstros" saídos da tela de cinema, a escola, mais uma vez, deixou de compreender e acompanhar a formação de novas possibilidades de interação com as novas mídias/tecnologias e novos imperativos políticos e econômicos, em função dos receios que já assinalava Walter Benjamin, no início da década de 1930:

El cine es la forma artística que corresponde al creciente peligro en que los hombres de hoy vemos nuestra vida. La necesidad de exponerse a efectos de choque es una acomodación del hombre a los peligros que le amenazan. El cine corresponde a modificaciones de hondo alcance en el aparato perceptivo $^{5}$ (BENJAMIN, 1989, p.52).

Diante de tais desafios, Benjamin concebe a complexidade no trato dessas imagens e o assume como edificante e formativo, ainda que invoque a seguinte reflexão: “¿No se alimentará la complacencia en el mundo de las imágenes de una obstinación sombría en contra del saber?”6 (BENJAMIN, 1989, p.152).

De forma antagônica à de Mercante e seus seguidores no "tom apocalíptico" e de desdém em que essas novas mídias foram concebidas, ${ }^{7}$ Benjamin não negligenciava essa nova atitude de conhecimento: a ruptura das distâncias, o imediatismo, as sensações, o ritmo, a imparcialidade, o sentimentalismo e a emotividade, assim como a abordagem "gigantesca" das imagens nas telas (DUSSEL, 2012), e, em relação a isso, a escola se afastava, já que privilegiava as ações pautadas na criticidade, reflexão, a moderação das emoções, a palavra antes do corpo, a observação a distância (DUSSEL, 2012).

Desse modo, a cultura escolar estabeleceu uma relação de estranheza e fobia, como salientou Angel Quintana (2012), com relação às tecnologias do século XX, e não somente à linguagem audiovisual, como também enfatizou Cuban (1986). À margem da história de outros meios de produção da cultura, de outras tradições e heranças culturais, a escola foi deixando possibilidades de lado. 


\section{Imagens na escola:}

\section{roteiros conhecidos e roteiros potenciais das ações educativas}

Conforme destacado, a utilização das imagens nas escolas, via de regra, é feita sob a égide de um de certo controle pedagógico, como destacam Abramowski (2012) e Serra (2012), uma vez que a principal pressuposição dessas práticas é "regular os olhares" discentes, seja para condicioná-los sob determinado foco analítico (em que ao educando cabe mais a passividade, se pudermos dizer assim), seja para converter os alunos em espectadores conscientes e críticos (o que tem sido considerado uma prática pedagógica mais positiva, herdeira dos movimentos da Escola Nova, que ficou conhecida como educação crítica do olhar). O fato é que, nas tarefas escolares com uso das imagens, o foco do trabalho tem-se voltado historicamente à direção/orientação do pensamento (ABRAMOWSKI, 2012, p.5).

Brea $(2007,2010)$ destaca que, nessa perspectiva considerada crítica, há uma preocupação em torno de um processo de visualização, ou seja, de desocultamento, em síntese. É importante observar que olhar criticamente se converteu em um desejo expoente/sinônimo de liberação, pois ver o que os outros não veem, de certo modo, libera e faz desenvolver outras perspectivas.

Nesse sentido, essa premissa da promoção dos olhares críticos está instalada já há algum tempo no campo educativo. Materializada em forma de programas, projetos, entre outros, tal ideia aparece largamente nos "manuais" com intuito de "formar espíritos, consciências, olhares, pensamentos, posições críticas" (ABRAMOWSKI, 2012, p.6-7).

Contudo, como apontado, em um passado não muito distante, as imagens foram consideradas uma fonte indigna dentro do campo das ciências sociais e humanas. Diferentemente dos textos escritos, eram consideradas como formas simples de informação. Nas palavras de Runge Peña (2012, p.1), eram tidas como "inocentes, explícitas, literales y de fácil acceso." Esse autor ressalta que, no campo da pedagogia visual, durante muito tempo, as imagens foram utilizadas como simples ilustrações ou como adornos do escrito, ocupando um lugar secundário em relação ao texto escrito.

Como se observa, de modo geral, como nos diz Ángel Quintana (2012), o fundamento da educação pela imagem é que, ao se projetar uma 
imagem, as coisas que não podiam ser vistas seriam possíveis. Abrem-se, portanto, muitas potencialidades. Contudo, destaca que, desde muito tempo, as formas pelas quais o cinema entra na escola têm problemas (e sabemos que não apenas os filmes são tratados de forma equivocada pedagogicamente; as imagens, as mídias e as tecnologias acabaram se tornando um "amálgama indigesto", ainda que necessário às escolas).

O primeiro problema que Quintana destaca é a crença na suposta transparência da imagem, como se esta fosse o mundo. Para o autor, a ilusão da transparência faz com que as segundas leituras não sejam habituais no sistema escolar: "entre lo obvio y lo obtuso que decía Barthes, la versión escolar se quedaba com lo obvio y no daba un paso hacia lo obtuso que encierra toda imagem", (QUINTANA, 2012, p.15).

Não menos importante é a priorização da educação em valores. Assim, através de um filme, busca-se gerar valores positivos para uma certa moral. Para Quintana (2012), isso se assemelha a uma doutrinação, a partir de certos recursos morais, e não a uma educação mais aberta e mais livre. ${ }^{10}$ Como salienta: "[...] cuando la escuela pretende reducir al cine a los valores obvios, camufla estas cosas, peca por excesiva" (QUINTANA, 2012, p.15). Uma última questão problemática diz respeito ao fato de que não se deve apenas pensar em "imagens nobres". Ao contrário disso, há que se olhar o conjunto das imagens da cultura contemporânea (em que se destacam os videojogos e os celulares, por exemplo), como objetos de temor pelas escolas, tornando-se formas marginais - e que poderiam contribuir enormemente para outras criações. ${ }^{11}$

Paradoxalmente, as imagens vão também ocupando outro status pedagógico, ${ }^{12}$ como destaca Runge Penãs:

Posturas pedagógicas, consecuentes con el presupuesto teórico-metodológico de que el saber pedagógico trasciende los ámbitos disciplinarios y científicos (Foucault, 1979; Zuluaga, 1987, 1999; Oelkers y Tenorth, 1993) y se aloja en lugares otrora poco tenidos en cuenta y concientes frente al hecho de que el texto escrito ya no se puede considerar como el único lugar privilegiado en el que se puede encontrar almacenada esa memoria histórica y cultural referida a la educación y formación humanas, han encontrado en las imágenes una fuente muy importante de saber pedagógico. Cada vez es más amplia la aceptación de que en las imágenes hay una fuente de saberes pedagógicos todavía por explorar y que ello amerita, por tanto, la consolidación de frentes de trabajo en los que se atienda a dicha labor ${ }^{13}$ (PENÃS, 2012, p.2). 
É nesse contexto predominante do século XX, como enfatizou Badiou (2007), que, apoiada pela busca incessante do esclarecimento/descortinamento/revelação, a pedagogia da imagem passará a suspeitar do "raso" que é a aparência, mas não a ignorará mais. Buscando a compreensão escondida no conteúdo das imagens, considera a forma uma estratégia a ser desfeita, pois pode enganar os olhares mais sagazes. Conforme a discussão de Serra (2012) em torno da educação cinematográfica, a sedução que exercem as imagens pode resultar em uma perigosa forma de submissão, balizada por olhares desavisados. Portanto, uma postura considerada crítica não prescindirá de olhares atentos, pois não se deixam seduzir e enganar.

As discussões em torno das práticas pedagógicas, desde muito tempo, como mencionado, deram-se conta do poder que exercem as imagens para atrair a atenção dos alunos, e mais: para atenuar as "dores" da aprendizagem. Nesse sentido, desde Comênius, no século XVII, vislumbramos tais percepções dos sentidos e a capacidade destacada de atrair, impressionar e motivar que podem desempenhar as imagens no campo educativo, como destacam Runge Peña (2012) e Abramowski (2012).

Para Comênius, a aprendizagem se inicia através das percepções e sentidos, com a intuição sensível. Segundo esse princípio, uma das maneiras de potencializar a educação é por meio da imagem. ${ }^{14}$ Como explica Runge Peña (2012, p.27) sobre o pensamento desse filósofo, "la imagen afecta la vista, deja una impresión más fuerte que lo verbal y fomenta la capacidad de hacer nuevas imágenes (imaginatio). En esa medida, la imagen es una pista sobre la cosa y su idea".

Vale ressaltar que as imagens são aqui concebidas como práticas sociais e não apenas como questões estritamente icônicas, como já apontado (DUSSEL, 2012). Nesse sentido, longe da neutralidade, são materializações de intencionalidades subjetivas e marcações ideológicas, portanto. ${ }^{15}$ Será nesse sentido que Malosseti Costa enfatizará que também

El poder de las imágenes, su capacidad para ser veneradas, despertar devociones y sostener creencias, generar violencia, ser odiadas, temidas y hasta destruidas, es algo que parece caer por fuera de la institución "arte", desbordando sus circuitos y mecanismos de legitimación en las sociedades occidentales modernas $^{16}$ (COSTA, 2012, p.1).

Para Abramowski (2012), o que se teme e se aborda com cuidado na perspectiva da pedagogia do "olhar crítico" é o caráter sedutor das 
imagens. Assim, quando, no campo educativo, se aconselha usar imagens como "disparadores" ou para chamar a atenção dos alunos, está-se apelando a essa tradição que concebe a imagem como uma fonte de sedução que arregimenta potencialidades ímpares - de ativação da atenção ou das emoções de quem observa - no âmbito pedagógico. Conforme enfatiza a autora, as imagens têm uma legítima capacidade de emocionar, de comover, de tocar "direto ao coração".

Contudo, essa relação íntima das imagens com as emoções e sentimentos também acaba sendo bastante questionável, pois traça uma dicotomia desnecessária entre razão (veiculada à palavra) e emoção (via imagens). Para Abramowski (2012, p.17), "nesta nova era da tirania emocional, interrogar-nos acerca do lugar que outorgamos às emoções em nossa prática pedagógica não tem por fim desautorizar os sentimentos, mas salientar quanto do emotivo se apresenta como ditatorial imperativo."17

Com intuito de escapar das tiranias hegemônicas e dos regimes de visibilidade ${ }^{18}$ contemporâneos (os que afetam os "atos de ver" e definem sistemas de crenças, como salientou Brea $(2007,2010))$, quais seriam então as potencialidades pedagógicas nesse âmbito? Qual seria o sentido de uma educação do olhar? Nessa direção, muito embora conheçamos o anacronismo das instituições escolares em relação aos anseios e desejos das novas gerações, quando se opta pelo uso das imagens e, portanto, por parte desse "mundo atual e glamoroso" - num movimento de resgate de "vida" e prazer" nas escolas - como se têm desenvolvido tais práticas pedagógicas na atualidade, quando o intuito é ensinarmos (e bem)? Há "brechas" nas regras da gramática escolar ${ }^{20}$ e diante dos regimes escópicos? Podemos ou devemos nos propor a "ensinar a olhar", sem incorrermos em riscos de uma "domesticação do olhar" e de pensamentos?

\section{Cenas dos próximos capítulos}

Concordando com Ángel Quintana (2012), a educação pela imagem deve ser proposta sob a égide da criticidade. Assim, poderemos saber como lê-la e como vê-la. É nesse sentido que enfatiza que é necessário buscar o obtuso e não só o óbvio.

Ainda que possamos conceber facilmente essa posição, é urgente também crermos na importância da desnaturalização da incorporação 
do cinema na aula (e das outras formas de imagens nas telas, que vão crescendo em larga escala: $i$-pads, i-phones, etc.) como chave do pensamento crítico, não apenas para inscrever o caráter histórico e contextualizado de um conjunto de práticas, mas como condição necessária para que outras abordagens sejam possíveis (não só em relação ao cinema, mas com a cultura em geral) (SERRA, 2012). Tal necessidade se dá em função do risco que corre o texto icônico de perder-se (ou tornar-se outra coisa), ao se submeter o olhar às regras escolares do pensar.

Como destaca Serra (2012, p.19), dando exemplo do que ocorre com o cinema: "hay un intraducible, um 'fuera de las palavras', una experiencia que resulta del ver cine, a la que algunos llaman experiencia cinematográfica, que excede incluso al pensamiento, de cualquier orden éste sea". Dessa maneira, como apontado, esse "fenômeno" parece ser inerente às imagens, de um modo geral.

Será nesse sentido que Quintana (2012) argumentará que a imagem não deve ser vista como uma janela para o mundo, mas um esconderijo: "não nos revela unicamente o que nos mostra, mas o que está mais além da própria imagem”"21 (QUINTANA, 2012, p.15). Isso, portanto, a pedagogia da imagem não deveria ignorar. Necessita criar as "brechas" na chamada gramática escolar, através da quebra de cânones e (pre)conceitos contra as formas narrativas, tecnológicas/midiáticas marginais, que "ousam competir" com a cultura nobre, e considerar que podemos fazer muitos outros usos desses mecanismos.

Assim, nosso compromisso, como educadores, deve ser vinculado à proposta de construção de uma memória visual distinta, o que significa trazer variadas imagens à escola, como destaca Quintana (2012): o que é considerado nobre e o que não é; o que é visível e o que é invisível. Esse autor também coloca em pauta o fato de que a experiência lúdica parece estar retirada dos espaços escolares, minando possibilidades de prazer e alegria no que é proposto e executado na cena pedagógica. Alerta-nos, portanto, para o fato de que é fundamental uma pedagogia realmente aberta e sem preconceitos: "que se plantee estas cuestiones, que entienda estos cambios en los regímeses de imágenes" (QUINTANA, 2012, p.23-24).

Temos um importante exemplo a esse respeito com o portal de educação argentino Educ.ar (www.educ.ar), um projeto lançado em julho de 2003, destinado a executar as políticas definidas pelo Ministério da 
Educação desse país, para a integração das Tecnologias da Informação e Comunicação (TICs) no sistema educativo. Segundo Piscitelli (2012), desde o início, os esforços do Educ.ar estiveram focados fundamentalmente no auxílio aos docentes e diretores de instituições educativas na incorporação das TICs na prática docente.

A partir da experiência do Educ.ar e de outros projetos de aprendizagem colaborativos, vislumbramos a necessidade premente de uma epistemologia/pedagogia que conceba o inacabado como essência. Isso significa dizer que as nossas práticas precisam, nesse modelo, de uma outra compreensão sobre o próprio conhecimento e como ele se dá. Aceitar sua incompletude como algo interessante e necessário faz com que nos coloquemos num movimento de tração e como mediadores, de fato. $^{22}$

Larrosa (2012) nos inspira a pensar sobre uma pedagogia da imagem que ensaia um tipo de olhar sobre o mundo e sobre a experiência humana (opaca, nebulosa, confusa). Imagens que façam perguntas (muitas vezes sem respostas), através de um olhar que sabe que apenas busca, que espera e segue; imagens que convocam um pensamento sobre o real que requer atenção e tempo, fugindo dos imediatismos e dos sentidos apriorísticos impostos pela atualidade.

Nessa direção, podemos lançar mão da concepção da ética do olhar (que nos diz algo sobre o agir), de que trata Jorge Larrosa (2012). Colocando-nos como educadores, diante do compromisso também político com a formação de nossos alunos, devemos nos arriscar na tarefa de uma vivência pedagógica com as imagens (olhar, sentir, refletir), assumindo que as situações sempre têm um fundo de mistério, de enigma, de desconhecido, que faz com que nunca possamos determiná-las. Da mesma forma, responder a essas questões, sem buscarmos a certeza das respostas corretas, porque não existem. Como Larrosa também defende:

[...] la situación ética nos exige dar una respuesta, que nunca podemos saber de antemano cuál es. Por eso tenemos que buscarla [...] Una ética en la que no estamos salvados para siempre, de una vez por todas, de antemano, sino que hay que buscar y encontrar la respuesta en cada caso, una y otra vez, cada vez de nuevo ${ }^{23}$ (LARROSA, 2012, p.11).

É lançarmo-nos ao outro, sem a ideia de que a ética seja uma faraônica busca do bem, mas uma singela resposta ao mal (talvez o mal 
por ignorarmos tantas possibilidades? Um mal por deixarmos nossos alunos à deriva?). Para Larrosa (2012, p.11), é uma ética da paixão (que evidencia uma dupla dimensão da relação eu/outro): "Y es una ética que hace indiscernibles la inquietud por el otro y la inquietud de sí." ${ }^{24}$

Assim, sem pretendermos didatizar, explicar, dissecar, depurar ou esquadrinhar a realidade e as atitudes humanas que as imagens nos apresentam, lançamo-nos, diante desses olhares, para o inexplicável que pode mobilizar e transformar algo (em nós e nos outros): o que nos afeta, no dizer de Benedictus de Spinoza (2011), em sua Ética.

\section{FIGURA 1}

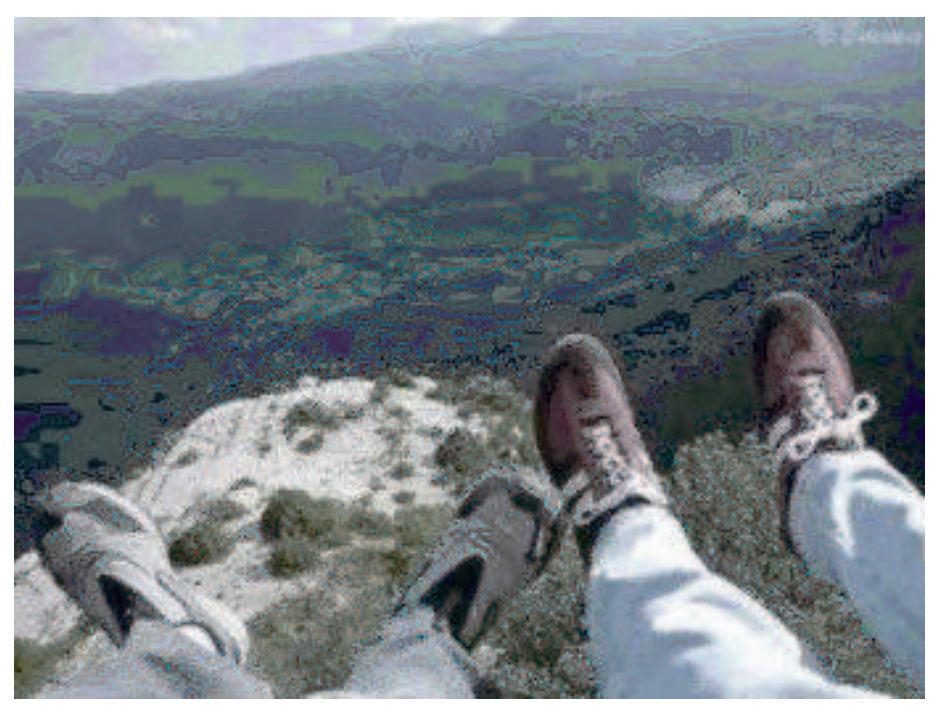

FONTE: http://gangstercolarinhomulticor.blogs.sapo.pt

“- Aproxime-se do precipício. - Não, vamos cair. - Aproxime-se do precipício. - Não, vamos cair. Eles se aproximaram do precipício. Ele a empurrou e eles voaram." (Guilherme Apollinaire) 


\section{NOTAS}

1 Livre tradução da autora.

2 Grifo da autora. Livre tradução: “[...] a que considerou desde cedo uma fonte de degeneração moral e intelectual da população - e isto é certo ainda para aqueles educadores envolvidos com a educação popular, que mantiveram essa mesma posição de desprezo moral à cultura de massa."

3 Idem ao anterior. Grifo da autora.

4 Dussel (2012) trata dessa questão, evidenciando antecedentes dos chamados novos meios/mídias/tecnologias, desde meados do século XI, e não só do século XX, como também assinala Lev Manovich (2006 apud DUSSEL, 2012, p.27).

5 Livre tradução: "O cinema é a forma artística que corresponde ao perigo crescente em que os homens de hoje veem a vida. A necessidade de expor-se a efeitos de choque é uma acomodação do homem aos perigos que lhe ameaçam. O cinema corresponde a modificações de profundo alcance no aparato perceptivo [...]".

6 Livre tradução: "A complacência não se alimentará, no mundo das imagens, de uma obstinação sombria contra o saber?”

7 Ver mais a esse respeito em Sztagnsrajber (2012).

8 Livre tradução da autora.

9 Livre tradução: "entre o óbvio e o obtuso que dizia Barthes, a versão escolar ficou com o óbvio e não dava um passo para o obtuso que encerra toda imagem”.

10 Serra (2012) também exemplifica práticas prescritivas para os educadores que se propunham à exibição de filmes nas escolas (nomeados diretores do cine-debate). Tratavase de uma "educação do olhar" com os filmes moralmente suspeitos, em meados da década de 60, e com fortes marcas ainda nos dias atuais.

11 Como exploração, prática e produção sobre ferramentas de desenvolvimento, assim como Google Maps, Flicker, blogs, Twitter, Youtube, My Space, Google Scholar, widgets, redes sociais, podcasts, buscas inteligentes, TV na internet, etc.

12 No Brasil, por exemplo, será na década de 70 que a produção de livros infantis irá enfatizar os aspectos gráficos, não mais vistos como subsidiários do texto, mas como elementos autônomos, como destacam Lajolo e Zilberman (2007). Assim, as imagens/ilustrações passam a incorporar a linguagem, rompendo a linearidade da palavra, trazendo significados ao texto ao lado da escrita e, em alguns casos, tornando-se capazes de assumir o centro da história. Como destaca Dalcin (2013, p.41), "a centralidade do texto verbal se desloca para a visualidade textual, para a configuração que se faz não só pelo que se diz pelas palavras, mas também pela imagem." Walty, Fonseca e Cury (2006) lembram que, atualmente, a leitura é concebida como um processo associativo que promove a interação da escrita e da imagem em múltiplos sentidos: "a imagem propriamente dita; a que ilustra textos verbais; aquela construída pelo leitor quando lê, que tanto pode restringir-se ao momento real de produção de sentido, como pode ser base de outras criações" (2006, p.7). 
13 Grifo da autora. Livre tradução: "Posturas pedagógicas, consequentes com o pressuposto teórico-metodológico de que o saber pedagógico transcende os âmbitos disciplinares e científicos (FOUCAULT, 1979; ZULUAGA, 1987, 1999; OELKERS; TENORTH, 1993) e se aloja em lugares antes pouco tidos em conta e conscientes frente ao fato de que o texto escrito já não se pode considerar como o único lugar privilegiado em que se pode encontrar armazenada essa memória histórica e cultural referida à educação e formação humanas, têm encontrado nas imagens uma fonte muito importante de saber pedagógico. Cada vez é mais ampla a aceitação de que, nas imagens, há uma fonte de saberes pedagógicos ainda a ser explorada, e isso garante, portanto, a consolidação de frentes de trabalho nessa direção."

14 É interessante lembrar que Comênius também foi uma fonte de inspiração para Rossellini, nos anos 60, quando o cineasta criava seu projeto didático para a televisão, como ressalta Ángel Quintana (2012).

15 Nesse sentido, Giroux (2003 apud SERRA, 2012) sustenta que os filmes devem ser abordados como parte das práticas de consumo cultural próprias de uma sociedade e como tais precisam ser revisados, analisados e criticados.

16 Livre tradução: “O poder das imagens, sua capacidade para serem veneradas, despertarem devoções e sustentarem crenças, gerarem violência, serem odiadas, temidas e até destruídas, é algo que parece ir além da instituição 'arte', transbordando seus circuitos e mecanismos de legitimação nas sociedades ocidentais modernas."

17 Livre tradução da autora.

18 Brea $(2007,2010)$ refere-se a tais regimes como sendo representantes das novas regras que ordenam a trama das visibilidades e que se apresentam com conflitos e com as velhas regras também (o que chamou de ideologia estética). Alguns desses traços seriam: "bombardeio" de imagens; mudanças subjetivas por este contato; explosão de imagens domésticas; a tendência a "espiar" a vida dos outros e a "exibir" a própria vida; imperativo entre ver, sentir e expor publicamente a intimidade; era da suspeita: ver para crer, particularmente quando se trata da televisão; multiplicação das imagens eletrônicas que duram pouco, que se retocam e manipulam; a "batalha" pela atenção e, por fim, um regime de visibilidade que se caracteriza como "hipervisibilidade" ou "visibilidades vorazes". Assim, trata-se de uma espécie de "pulsão escópica", como dizem os psicanalistas: um “apetite" por ver (ANTELO, 2008).

19 A esse respeito, consultar a obra de Peter Cryle, que fala do "Kama Sutra como currículo". Nessa perspectiva, o desejo e o prazer também se educam, e, para isso, é necessário romper com uma visão romântica de que o natural e o espontâneo estão fora do discurso e das aprendizagens sociais, assim como com o fato de que qualquer ensino seja pouco autêntico, repressivo e artificial (DUSSEL, 2012).

20 Para Dussel (2012), a gramática escolar refere-se à ideia de uma "matriz de tradução" e produção de experiências que baliza os novos saberes e as mudanças nas relações entre as gerações. Seria uma espécie de macro-estrutura para o funcionamento das ações pedagógicas.

21 Livre tradução da autora. 
22 Conforme a autora argumentou no Fórum 4 do curso Educación, imágenes y medios Cohorte 8.

23 Livre tradução: “[...] a situação ética nos exige dar uma resposta, que nunca podemos saber de antemão qual é. Por isso temos que buscá-la [...] Uma ética em que não estamos salvos para sempre, de uma vez por todas, de antemão, mas que é necessário buscá-la e encontrar a resposta em cada caso, uma outra vez, cada vez de novo".

24 Livre tradução: "É uma ética que faz indiscerníveis a inquietude pelo outro e a inquietude de si".

\section{REFERÊNCIAS}

ABRAMOWSKI, A. ¿Cómo mirar, mostrar, sentir y enseñar en un mundo que mira, muestra y siente demasiado? Curso: Educación, i mágenes y medios. Grupo 8. 2012. Disponível em: http://virtual.flacso.org.ar/mod/book/view.php?id=5845. Acesso em: 14 dec. 2012.

ANTELO, M. O apetite do olho, a anorexia do olhar. Revista de Psicologia Plural, Belo Horizonte, v.25, p.103-122, 2008.

BADIOU, A. O século. Aparecida, SP: Idéias \& Letras, 2007.

BENJAMIN, W. Discursos interrumpidos I: filosofia del arte y de la historia. Buenos Aires: Taurus, 1989.

BREA, J. L. Cambio de régimen escópico: del inconsciente óptico a la e-image. Revista Estudios Visuales, Murcia/España, n.2(4), p.145-163, 2007.

BREA, J. L. Las tres eras de la imagem: imagen-materia, film, e-imagen. Ediciones Akal, 2010. Disponível em:

http:/ / books.google.com.br/books?id=IBXMDNv8jH0C\&lpg=PP1\&dq=las $\% 20$ tres $\% 20 \operatorname{eras}^{2} 20 \mathrm{de} \% 201 \mathrm{a} \% 20 \mathrm{imagen} \& \mathrm{hl}=\mathrm{pt}-\mathrm{BR} \& \mathrm{pg}=\mathrm{PP} 1 \mathrm{Z}_{\mathrm{v}}=$ onepage\&q=las $\% 20 \operatorname{tres} \% 20$ eras $\% 20 \mathrm{de} \% 201 \mathrm{a} \% 20$ imagen\&f=false. Acesso em: 02 dec. 2013.

CUBAN, L. Teachers and machines: the classroom use of technology since 1920. New York: Teacher's College Press, 1986. Disponível em:

http:/ / books.google.com.br/books?id=uQeEn1 vEUSQC\&printsec $=$ frontcover\&hl=p t-BR\&source=gbs_ge_summary_r\&cad $=0 \#_{\mathrm{v}}=$ onepage\&q\&f=false. Acesso em: 21 jan. 2014. DALCIN, A. R. Um escritor e ilustrador (Odilon Moraes), uma editora (Cosac Naify): criação e fabricação de livros de literatura infantil. 224f. Dissertação (Mestrado em Educação) Faculdade de Educação da UNICAMP, São Paulo, 2013.

DUSSEL, I. Escuela y cultura de la imagem: los nuevos desafíos. Curso: Educación, i mágenes y medios. Grupo 8. 2012. Disponível em:

http://virtual.flacso.org.ar/mod/book/view.php?id=5845. Acesso em: 14 dec. 2011.

LAJOLO, M.; ZILBERMAN, R. Literatura infantil brasileira: histórias e histórias. 6.ed. São Paulo: Ática, 2007. (Série Fundamentos).

LARROSA, J. Palavras e imágenes para una ética de la mirada. Curso: Educación, $i$ mágenes y medios. Grupo 8. 2012. Disponível em: 
http://virtual.flacso.org.ar/mod/book/view.php?id=5845. Acesso em: 10 nov. 2012. MALOSSETI COSTA, L. La imagen en la cultura occidental. Curso: Educación, i mágenes y medios. Grupo 8. 2012. Disponível em:

http://virtual.flacso.org.ar/mod/book/view.php?id=5845. Acesso em: 27 jul. 2012. PISCITELLI, A. Portales educativos. El caso Educ.ar. Curso: Educación, i mágenes y medios. Grupo 8. 2012. Disponível em:

http://virtual.flacso.org.ar/mod/book/view.php?id=5845. Acesso em: 04 dec. 2012. QUINTANA, Á.; DUSSEL, I. Entre lo obvio y lo obtuso: notas sobre cine y educación. Curso: Educación, i mágenes y medios. Grupo 8. 2012. Disponível em:

http://virtual.flacso.org.ar/mod/book/view.php?id=5845. Acesso em: 13 dec. 2012.

RUNGE PEÑA, A. K. El saber pedagógico en las imágenes y las imágenes en el saber pedagógico. Curso: Educación, i mágenes y medios. Grupo 8. 2012. Disponível em: http://virtual.flacso.org.ar/mod/book/view.php?id=5845. Acesso em: 13 oct. 2012. SERRA, M. S. Usos del cine en el escenario pedagógico: pensar, debatir, criticar. Curso: Educación, i mágenes y medios. Grupo 8. 2012. Disponível em:

http://virtual.flacso.org.ar/mod/book/view.php?id=5845. Acesso em: 13 dec. 2012. SONTAG, S. Diante da dor dos outros. São Paulo: Companhia das Letras, 2003.

SPINOZA, B. de. Ética. 2.ed. Belo Horizonte: Autêntica, 2011.

SZTAGNSRAJBER, D. Abordaje sobre lo humano y la tecnología. Curso: Educación, i mágenes y medios. Grupo 8. 2012. Disponível em:

http://virtual.flacso.org.ar/mod/book/view.php?id=5845. Acesso em: 28 oct. 2012.

WALTY, I. L. C.; FONSECA, M. N. S.; CURY, M. Z. F. Palavra e imagem: leituras cruzadas. 2.ed. Belo Horizonte: Autêntica, 2006.

Recebido em: 29/05/2013

Aprovado em: 28/01/2014

\author{
Contato: \\ Departamento de Psicologia Educacional \\ Cidade Universitária "Zeferino Vaz" \\ Avenida Bertrand Russell, 801 \\ CEP 13083-865 \\ Campinas | SP | Brasil
}


